\title{
Derivatives of (phenylsulfonamido-methyl)nicotine and (phenylsulfonamido-methyl)thiazole as novel 11ß-hydroxysteroid dehydrogenase type 1 inhibitors: synthesis and biological activities in vitro
}

\author{
Xu ZHANG*, Yang ZHOU*, Yu SHEN, Li-li DU, Jun-hua CHEN, Ying LENG* , Jian-hua SHEN* \\ State Key Laboratory of Drug Research, Shanghai Institute of Materia Medica, Chinese Academy of Sciences, Zhangjiang Hi-Tech Park, \\ Shanghai 201203, China
}

Aim: To design and synthese a novel class of 11ß-hydroxysteroid dehydrogenase type 1 (11ß-HSD1) inhibitors, featuring the (phenylsulfonamido-methyl)pyridine and (phenylsulfonamido-methyl)thiazole framework.

Methods: Our initial lead 4-(phenylsulfonamido-methyl)benzamides were modified. Inhibition of human and mouse 11ß-HSD1 enzymatic activities by the new compounds was determined by a scintillation proximity assay (SPA) using microsomes containing $11 \beta$ HSD1.

Results: Sixteen new compounds (6a-6h, 7a-7h) were designed, synthesized and bioassayed. In dose-response studies, several compounds showed strong inhibitory activities with $\mathrm{IC}_{50}$ values at nanomolar or low nanomolar concentrations. Structure-activity relationships are also discussed with respect to molecular docking results.

Conclusion: This study provides two promising new templates for 11ß-HSD1 inhibitors.

Keywords: 11ß-hydroxysteroid dehydrogenase type 1; inhibitors; molecular modeling

Acta Pharmacologica Sinica (2009) 30: 1344-1350; doi: 10.1038/aps.2009.118; published online 24 August 2009

\section{Introduction}

Metabolic syndrome is a cluster of factors associated with an increased risk of atherosclerotic cardiovascular disease and diabetes. The characteristics of metabolic syndrome include central obesity, insulin resistance, atherogenic dyslipidemia, and hypertension ${ }^{[1]}$. Recent investigations have indicated that glucocorticoid excess in tissues such as liver and adipose might contribute to the development of metabolic syndrome ${ }^{[2,3]}$. Glucocorticoid hormones are important metabolic regulators. The major glucocorticoid in humans is cortisol. Cortisol concentration in target tissues is modulated by two tissue-specific enzymes: $11 \beta$-hydroxysteroid dehydro-

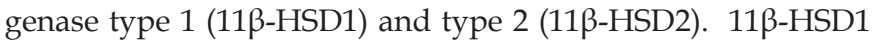
converts inactive cortisone into receptor-active glucocorticoid cortisol, which is highly expressed in the liver, adipose tissue,

\footnotetext{
\# Authors contributed equally to this work.

* To whom correspondence should be addressed.

E-mail yleng@mail.shcnc.ac.cn (Prof Ying LENG) and jhshen@mail.shcnc. ac.cn (Prof Jian-hua SHEN).

Received 2009-05-04 Accepted 2009-07-07
}

and the central nervous system, whereas $11 \beta$-hydroxysteroid dehydrogenase type 2 (11 $\beta$-HSD2) converts cortisol into cortisone and is primarily expressed in the kidney, the colon, and other tissues (Figure 1$)^{[4,5]}$. Inhibition of $11 \beta-H S D 2$ can lead to sodium retention, hypokalemia, and hypertension ${ }^{[4]}$; therefore, inhibitors should be selective for $11 \beta$-HSD1 over $11 \beta-H S D 2$.

A potential role for $11 \beta$-HSD1 inhibitors in metabolic disease in vivo has been demonstrated using a transgenic mouse approach. Mice overexpressing $11 \beta$-HSD1 in adipose tissue showed metabolic syndrome-like phenotypes such as central obesity, glucose intolerance, and insulin resistance ${ }^{[6,7]}$. In contrast, 11 $\beta$-HSD1 deficient mice were resistant to the development of high-fat diet-induced obesity and exhibited improved insulin sensitivity and lipid profiles ${ }^{[8,9]}$. These data suggest that $11 \beta$-HSD1 could be a drug target for the treatment of metabolic syndromes, such as type 2 diabetes.

In the past few years, a number of small molecule inhibitors of 11 $\beta$-HSD1 have been discovered (Figure 2), and Incyte's small molecule inhibitor INCB-13739 is currently in phase II clinical trials ${ }^{[10]}$.

Work from our laboratories has demonstrated that 4-(phe- 


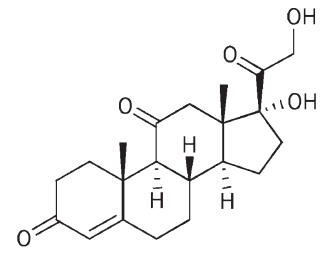

Cortisone

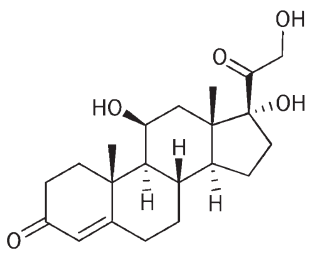

Cortisol
Figure 1. Interconversion of cortisone and cortisol by 11ß-HSD type 1 and 2.<smiles>Cc1c(Cl)cccc1S(=O)(=O)Nc1nc(CC(=O)N2CCN(C)CC2)cs1</smiles>

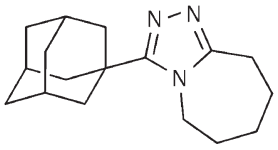

Merck 544

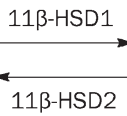

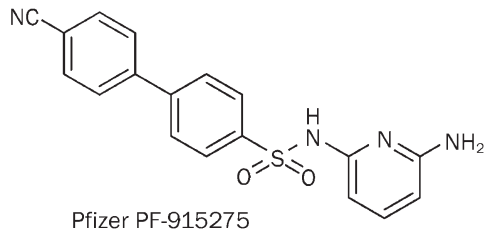

Figure 2. Representative selective 11ß-HSD1 inhibitors.

nylsulfonamidomethyl)benzamides (Figure 3) are inhibitors of 11 $\beta$-HSD1[unpublished data]. In particular, highly potent

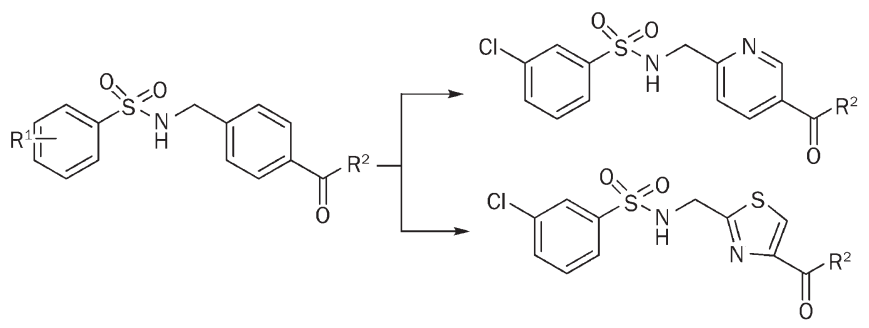

$\mathrm{R}^{1}=3-\mathrm{Cl} ; 2-\mathrm{Cl} ; 4-\mathrm{Cl} ; 2,5-\mathrm{diCl} ; 4-\mathrm{F} ; 4-\mathrm{CH}_{3} ; 3-\mathrm{Cl}, 4-\mathrm{F} ; 4-\mathrm{CF}_{3} ; 3-\mathrm{CF}_{3}$; 2-Cl, 4-F; 2- $\mathrm{CH}_{3}, 3-\mathrm{Cl}$
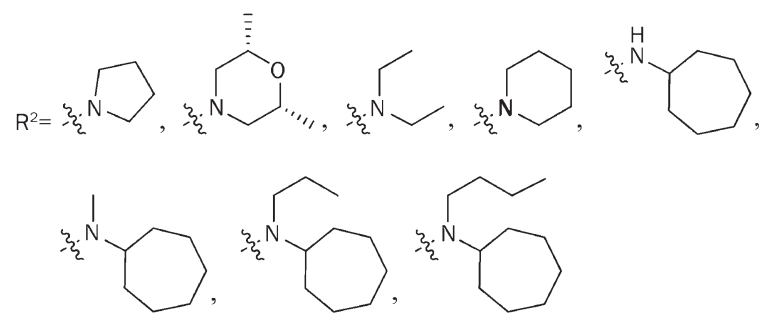

Figure 3. General structure of active 11ß-HSD1 inhibitors, 4-(phenylsulfonamidomethyl)benzamides and their analogues. compounds are obtained when $\mathrm{R}^{1}$ is $3-\mathrm{Cl}$ in combination with various secondary amines at the $\mathrm{R}^{2}$ position. As an extension of this work, the analogues (phenylsulfonamido-methyl)pyridine and (phenylsulfonamido-methyl)thiazole (Figure 3) were investigated.

\section{Materials and methods} Synthetic procedures

(Phenylsulfonamido-methyl)pyridines and (phenylsulfonamido-methyl)thiazoles were prepared via the route shown in Scheme 1-3. Hydrogenation of the 6-cyanonicotinic acid (1) catalyzed by $10 \% \mathrm{Pd} / \mathrm{C}$ afforded 2 in excellent yields. Protection of the acid 2 using methyl ester by Fischer esterification with acidic methanol gave the key intermediate $\mathbf{3 a}$, whereas $3 \mathbf{b}$ was prepared according to the four-step process described in the literature ${ }^{[11]}$. Sulfonylation of the amino ester $3 \mathbf{a}$ or $3 \mathbf{b}$ using 3-chlorobenzenesulfonyl chloride in the presence of triethylamine afforded intermediate 4. Hydrolysis of ester 4 in methanol using potassium hydroxide gave carboxylic acid 5 in high yields. Final products 6 and 7 were obtained by treatment of intermediate acid 5 with various amines using 1-hydroxybenzotriazole and 1-[3-(dimethylamino)propyl]-3ethylcarbodiimide hydrochloride as amide-coupling reagents. The non-commercially available variants of N-substituted cycloheptanamine 8 were prepared according to methodologies described in the literature ${ }^{[12]}$.

\section{Scintillation proximity assay (SPA)}

Inhibition of mouse or human 11ß-HSD1 enzymatic activities was determined by the scintillation proximity assay (SPA) using microsomes containing $11 \beta$-HSD1 according to previous studies ${ }^{[13,14]}$. Briefly, the full-length $c D N A s$ of human and murine $11 \beta$-HSD1 were isolated from cDNA libraries provided by the NIH Mammalian Gene Collection and cloned into the pcDNA3 expression vector (Invitrogen, Carlsbad, Ca, USA) by PCR. HEK293 cells were transfected with the pcDNA3derived expression plasmids and selected by cultivation in the presence of $700 \mu \mathrm{g} / \mathrm{mL}$ G418. Microsomal fractions overexpressing $11 \beta$-HSD1 were prepared from HEK293 cells stably transfected with $11 \beta$-HSD1 and used as the enzyme source for SPA. The assay was performed in a 96-well microtiter plate. Different concentrations of compound were added, followed by the addition of $80 \mu \mathrm{L}$ of $50 \mathrm{mmol} / \mathrm{L}$ HEPES buffer, $\mathrm{pH}$ 7.4, containing $25 \mathrm{nmol} / \mathrm{L}\left[1,2-(\mathrm{n})^{3} \mathrm{H}\right]$ cortisone (Amersham, Buckinghamshire, UK) and $1.25 \mathrm{mmol} / \mathrm{L} \mathrm{NADPH}$. Reactions were initiated by the addition of the 11ß-HSD1 enzyme preparation as microsomal fractions from HEK293 cells in a final concentration of $80 \mu \mathrm{g} / \mathrm{mL}$ of $11 \beta-H S D 1$. After incubation for $60 \mathrm{~min}$ at $37^{\circ} \mathrm{C}$, the reaction was stopped by the addition of $35 \mu \mathrm{L}$ of $10 \mathrm{mg} / \mathrm{mL}$ protein A-coated SPA beads (GE, Piscataway, NJ, USA) suspended in Superblock ${ }^{\circledR}$ Blocking Buffer (Pierce, Rockford, IL) with $3 \mu \mathrm{g} / \mathrm{mL}$ of murine monoclonal cortisol antibody (East Coast Biologics, North Berwick, Maine, USA) and $314 \mu \mathrm{mol} / \mathrm{L}$ glycyrrhetinic acid (Sigma-Aldrich, St Louis, $\mathrm{MO})$. The plates were incubated under plastic film on an orbital shaker for $120 \mathrm{~min}$ at room temperature. The $\left[{ }^{3} \mathrm{H}\right]$ cor- 
<smiles>CCOC(=O)c1ccc(CNS(=O)(=O)c2cccc(Cl)c2)cc1</smiles><smiles>[R]C(=O)c1ccc(CNS(=O)(=O)c2cccc(Cl)c2)cc1</smiles><smiles></smiles><smiles>CCCCN(CCCC)C1CCCCCC1</smiles>

Scheme 1. Reagents and conditions: (a) $\mathrm{H}_{2}, \mathrm{Pd} / \mathrm{C}, \mathrm{MeOH}$; (b) $\mathrm{SOCl}_{2}, \mathrm{MeOH}$, reflux; (c) 3-chlorobenzenesulfonyl chloride, $\mathrm{Et}_{3} \mathrm{~N}, \mathrm{CH}_{2} \mathrm{Cl}_{2}$; (d) 1 mol/L $\mathrm{KOH}$, $\mathrm{MeOH}$, reflux; (e) $\mathrm{HOBt}, \mathrm{EDCl}, \mathrm{CH}_{2} \mathrm{Cl}_{2}$.

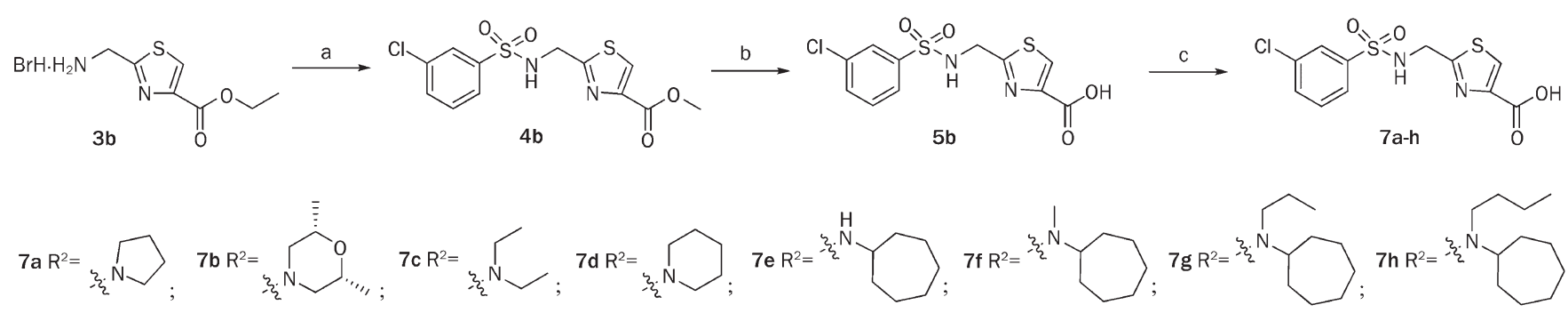

Scheme 2. Reagents and conditions: (a) 3-chlorobenzenesulfonyl chloride, $\mathrm{Et}_{3} \mathrm{~N}, \mathrm{CH}_{2} \mathrm{Cl}_{2}$; (b) $1 \mathrm{~mol} / \mathrm{L} \mathrm{KOH}, \mathrm{MeOH}, \mathrm{reflux} ;(\mathrm{c}) \mathrm{HOBt}, \mathrm{EDCl}, \mathrm{CH}_{2} \mathrm{Cl}_{2}$.

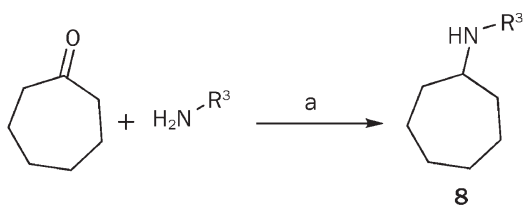

$\mathrm{R}^{2}=\mathrm{Me}, \mathrm{Et}, \mathrm{n}-\mathrm{Pr}, \mathrm{n}-\mathrm{Bu}$

Scheme 3. Reagents and conditions: (a) i: $\mathrm{Ti}\left(\mathrm{O}^{\mathrm{P}} \mathrm{Pr}\right)_{4}$; ii: $\mathrm{NaBCNH}_{3}$.

tisol generated in the enzymatic reaction was captured by the beads and measured in a liquid scintillation counter equipped to read microplates. Percentage inhibition was calculated relative to an uninhibited control. Data were obtained from at least three independent experiments. $\mathrm{IC}_{50}$ values were calculated using Prism Version 4 (GraphPad Software, San Diego, CA).

\section{Molecular docking}

Crystal structures of several human $11 \beta-H S D 1$ complexes and one murine 11 $\beta$-HSD1 complex were acquired from the Protein Data Bank. A structural alignment protocol within Discovery Studio ${ }^{[15]}$ was used to compare these structures. Finally, PDB entries 3CZR, 2IRW (human) and 1Y5R (murine) were chosen for the following docking study employing Schrödinger Glide ${ }^{[16]}$.

The NADPH cofactor observed in the PDB structure was retained to mimic the real inhibition process, forming a complex receptor with 11ß-HSD1. Protein Preparation and Grid Preparation tools in Schrödinger Maestro were used for receptor preparation. A neutralization zone was defined around the ligand during the refinement process. The original location of small molecules in the published PDB structure was set as the binding site for Receptor Grid Generation. All compounds were docked in extra precision (XP) mode and output files were compiled from 50 poses with the highest G-score per ligand to ensure that a variety of binding modes were explored with high accuracy. Pose with RMSD values less than $0.5 \AA$ were discarded as duplicates to simplify subsequent analysis. 


\section{Results}

Inhibitor design and synthesis

On the basis of the structure of 4-(phenylsulfonamidomethyl) benzamides, which were previously discovered in our laboratories to be $11 \beta$-HSD1 inhibitors, their analogues (phenylsulfonamido-methyl)nicotines and (phenylsulfonamido-methyl) thiazoles were designed and synthesized; their chemical structures are shown in Table 1. These compounds were synthesized according to the route outlined in Figure 4, and the details of the synthetic procedures are described in the Appendix.

\section{Biological assay}

The inhibitory properties of the synthesized molecules were evaluated in a scintillation proximity assay (SPA) with human and mouse 11ß-HSD1 (from HEK293 cells transfected with a full-length pcDNA3-derived expression plasmid). For the primary assay, percentage inhibition of $11 \beta$-HSD1 was measured at a concentration of $1 \mu \mathrm{mol} / \mathrm{L}$ of each small molecule. The results are summarized in Table 1 . To determine the exact potency of the compounds that exhibited significant inhibitory activities (percentage inhibition at $1 \mu \mathrm{mol} / \mathrm{L}>50 \%$ ), eight compounds $(6 \mathbf{e}-6 \mathbf{h}, 7 \mathbf{e}-7 \mathbf{h})$ were further investigated in doseresponse studies (Table 2 ).

\section{Molecular modeling}

In order to obtain insight into the possible binding mode, docking experiments were conducted using the Glide program. All compounds were docked into three $X$-ray crystal structures, 3CZR, 2IRW (human) and 1Y5R (murine). Several conformations were retained in a single docking output file. Almost all compounds showed a similar binding mode, which appeared in most poses with the highest G-score. The complex of $\mathbf{6 f}$ and $3 \mathrm{CZR}$ is shown as an example (Figure 4) to illustrate the general pose for the two series of $11 \beta$-HSD1 inhibitors. Two hydrogen bonds and a hydrophobic interaction were observed and are discussed in the following section.

\section{Discussion}

As shown in Table 1, the 11 -HSD1 inhibitory activities of

Table 1. Activities of compounds 6 and 7 against human and mouse 11ß-HSD1.

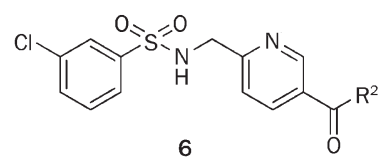

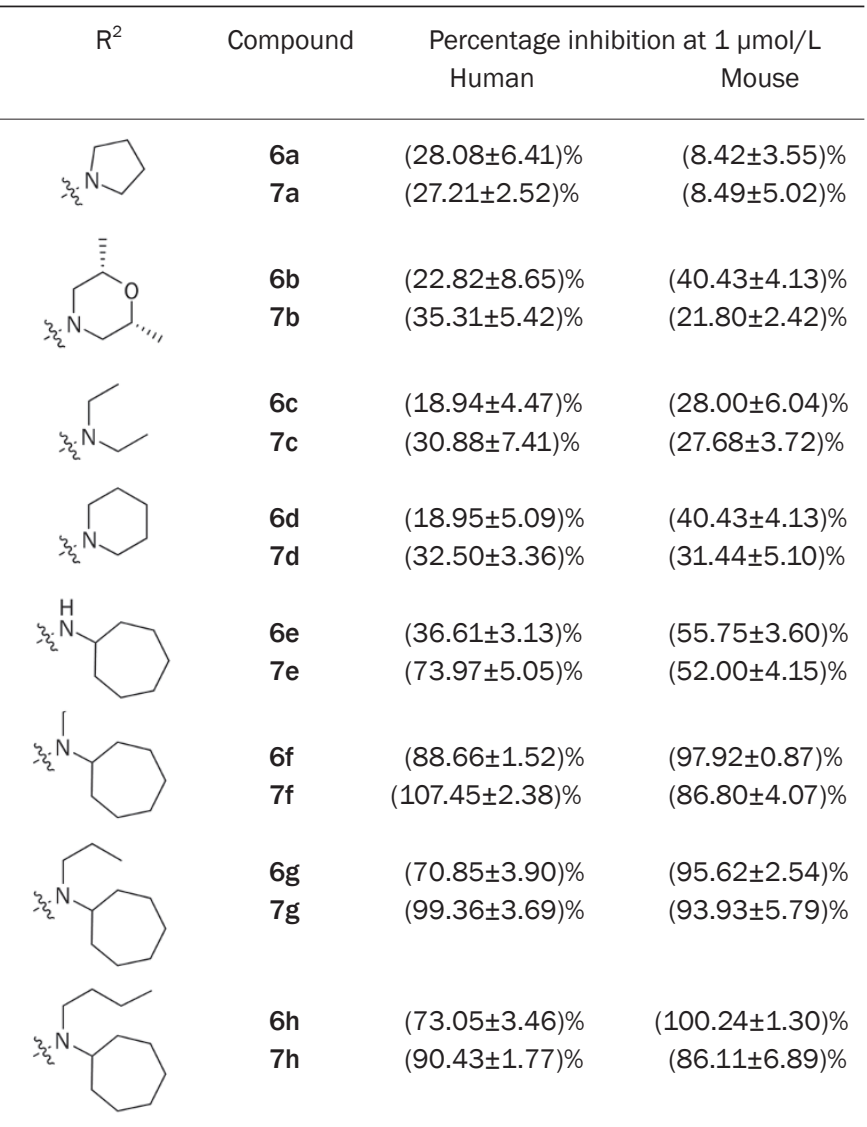

(phenylsulfonamido-methyl)nicotines 6 and (phenylsulfonamido-methyl)thiazoles 7 followed a similar trend. When $\mathrm{R}_{2}$ was pyrrolidine, $(2 R, 6 S)$-2,6-dimethylmorpholine, diethylam-
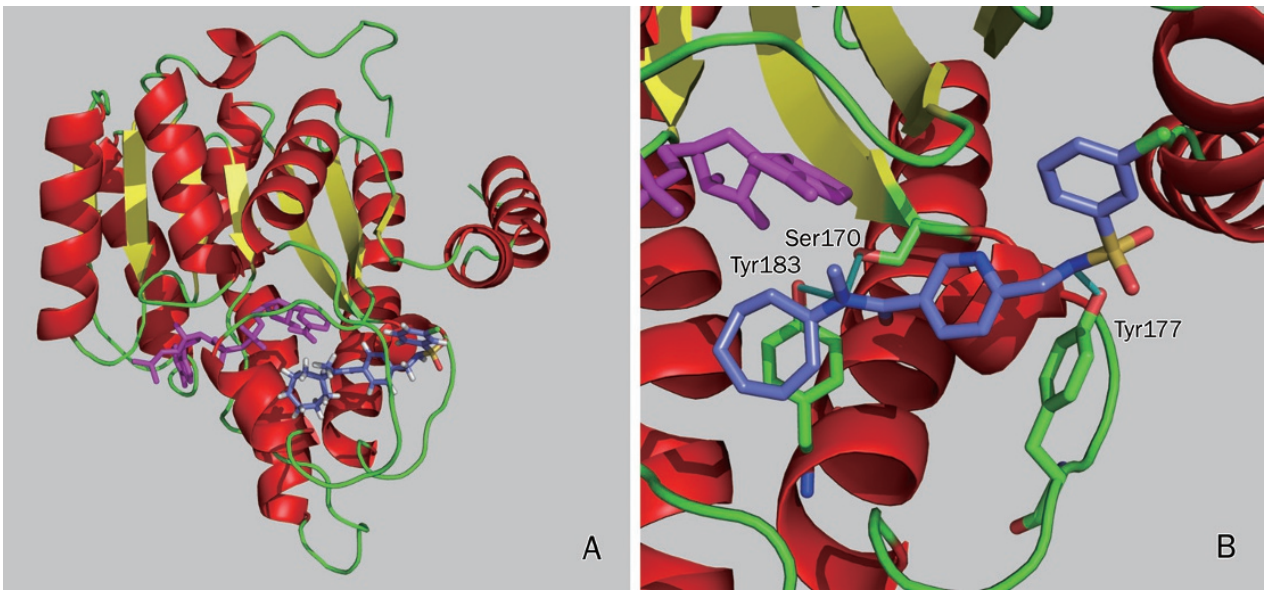

Figure 4. The binding mode of $6 \mathrm{f}$ and human 113-HSD1 (PDB: 3CZR) is illustrated by the $\mathrm{PyMOL}^{[17]}$ program in a global view (A) and close-up (B). The small molecule colored magenta is the cofactor NADPH. Predicted hydrogen bond interactions are represented by the cyan "sticks". 
Table 2. Determination of $\mathrm{IC}_{50}$ of selected compounds.

\begin{tabular}{ccc}
\hline Compound & \multicolumn{2}{c}{$\mathrm{IC}_{50}(\mathrm{nmol} / \mathrm{L})$} \\
& Human & Mouse \\
\hline $6 \mathrm{e}$ & - & $849 \pm 145$ \\
$7 \mathrm{e}$ & $222 \pm 72$ & $1055 \pm 150$ \\
$6 \mathrm{f}$ & $57 \pm 3$ & $45 \pm 6$ \\
$7 \mathrm{f}$ & $6 \pm 1$ & $307 \pm 122$ \\
$6 \mathrm{~g}$ & $375 \pm 47$ & $80 \pm 29$ \\
$7 \mathrm{~g}$ & $78 \pm 16$ & $279 \pm 33$ \\
$6 \mathrm{~h}$ & $143 \pm 42$ & $24 \pm 6$ \\
$7 \mathrm{~h}$ & $84 \pm 10$ & $210 \pm 49$ \\
\hline
\end{tabular}

ine, or piperidine $(6 \mathbf{a}-6 \mathbf{d}, 7 \mathbf{a}-7 \mathbf{d})$, the compounds showed modest inhibitory activities. Replacing them with cycloheptanamine (6e and 7e) resulted in an approximately 2-fold increase in inhibition; alkylating the nitrogen atom of the amide $(\mathbf{6 f}-\mathbf{6 h}, \mathbf{7 f - 7 h})$ further enhanced the potency.

Molecular modeling experiments were carried out to investigate the binding interactions between this series of compounds and the active site of $11 \beta$-HSD1. Using compound $6 f$ as an example, the N-cycloheptanyl moiety binds to a hydrophobic pocket consisting of residues Ala223, Ala226, Ile121, Val180, and Leu126. The cycloheptanyl group displays more appropriate hydrophobic binding than corresponding piperidine and other groups, illustrated by the increased potency from $\mathbf{a}-\mathbf{d}$ to $\mathbf{e}-\mathbf{h}$. A hydrogen bond was found in our docking results, formed by $\mathrm{H}$-bond donor Tyr183 or nearby residue Ser170 and the H-bond acceptor amide group. Increased activity exhibited by compounds with an alkyl group at the amino position ( $\mathbf{f}-\mathbf{h})$ may be attributed to an increase in electron density at the amide group, which may strengthen the hydrogen bond interaction. The hydrogen bond between Tyr183/ Ser170 and the ligands could often be identified in various $X$-ray structures, indicating an important pharmacophore of $11 \beta$-HSD1 inhibitors. Another hydrogen bond was also found proximal to Tyr177.

In summary, two series of novel (phenylsulfonamidomethyl)nicotines and (phenylsulfonamido-methyl)thiazoles were synthesized. All of the compounds were evaluated in a scintillation proximity assay (SPA) against human and mouse $11 \beta$-HSD1 with the aim of identifying potential $11 \beta-H S D 1$ inhibitors endowed with positive pharmacological profiles for the treatment of metabolic diseases. In dose-response studies, several compounds showed prominent inhibitory activities with $\mathrm{IC}_{50}$ values in the nanomolar or low nanomolar ranges. Molecular modeling studies for $6 \mathrm{f}$ were also performed to demonstrate the binding modes between the ligands and receptors; information gleaned from the models will aid in further lead optimization.

\section{Appendix}

Reagents were purchased from Lancaster, Acros and Shanghai Chemical Reagent Company and used without further purifica- tion. Analytical thin-layer chromatography (TLC) was performed with HSGF 254 (150-200 $\mu \mathrm{m}$ thickness, Yantai Huiyou Company, China). Yields were not optimized. ${ }^{1} \mathrm{H}$ NMR spectral data were recorded in DMSO- $d_{6}, \mathrm{D}_{2} \mathrm{O}$ or $\mathrm{CDCl}_{3}$ on Varian Mercury 400 or 300 NMR spectrometer. Chemical shifts were reported in parts per million (ppm, $\delta$ ) downfield from tetramethylsilane. Proton coupling patterns were described as singlet (s), doublet (d), triplet $(\mathrm{t})$, quartet $(\mathrm{q})$, multiplet $(\mathrm{m})$, or broad (br). Low- and high-resolution mass spectra (LRMS and HRMS) were obtained by electric, electrospray and matrix-assisted laser desorption ionization (EI, ESI and MALDI) produced by Finnigan MAT-95, LCQ-DECA and IonSpec 4.7 Tesla spectrometers, respectively.

\section{6-(Aminomethyl)nicotinic acid (2)}

6-Cyanonicotinic acid ( $3 \mathrm{~g}, 20 \mathrm{mmol})$ was added to a suspension of $10 \% \mathrm{Pd} / \mathrm{C}(300 \mathrm{mg})$ in $\mathrm{MeOH}(100 \mathrm{~mL})$ and pressurized with 1 bar of hydrogen gas. The mixture was stirred at room temperature for $4 \mathrm{~h}$. The precipitate was redissolved by the addition of water and the resulting mixture was filtered. The filtrate was evaporated to dryness to give 2 as a pale solid. Yield: 59\%. ${ }^{1} \mathrm{H}$ NMR $\left(\mathrm{D}_{2} \mathrm{O}, 400\right.$ MHz): $\delta 4.27$ (s, 2H), $7.31(\mathrm{~m}, 1 \mathrm{H}), 8.11(\mathrm{~m}, 1 \mathrm{H}), 8.83(\mathrm{~m}, 1 \mathrm{H})$.

\section{Methyl 6-(aminomethyl)nicotinate hydrochloride (3a)}

6-(Aminomethyl)nicotinic acid 2 (1.5 g, $9.9 \mathrm{mmol})$ in $\mathrm{MeOH}(200$ $\mathrm{mL})$ was treated with $\mathrm{SOCl}_{2}(2 \mathrm{~mL})$ and refluxed at $70{ }^{\circ} \mathrm{C}$ overnight. The solvent was removed under reduced pressure to give 3 as a brown solid. Yield: $94 \% .{ }^{1} \mathrm{H}$ NMR (DMSO, $\left.300 \mathrm{MHz}\right): \delta 3.89$ $(\mathrm{s}, 3 \mathrm{H}), 4.29(\mathrm{~s}, 2 \mathrm{H}), 7.64(\mathrm{~m}, 1 \mathrm{H}), 8.34(\mathrm{~m}, 1 \mathrm{H}), 9.08(\mathrm{~m}, 1 \mathrm{H})$.

\section{Methyl 6-[(3-chlorophenylsulfonamido)methyl]nicotinate (4a)}

3-Chlorobenzenesulfonyl chloride $\left(211 \mathrm{mg}, 0.1 \mathrm{mmol}\right.$ ) and $\mathrm{Et}_{3} \mathrm{~N}$ $(1 \mathrm{~mL})$ were added to a suspension of methyl 6-(aminomethyl) nicotinate hydrochloride $(239 \mathrm{mg}, 0.1 \mathrm{mmol})$ in $\mathrm{CH}_{2} \mathrm{Cl}_{2}(20 \mathrm{~mL})$. The mixture was stirred at room temperature for $6 \mathrm{~h}$. The reaction mixture was washed successively with $1 \mathrm{~mol} / \mathrm{L} \mathrm{HCl}(2 \times 20$ $\mathrm{mL})$ and saturated $\mathrm{NaHCO}_{3}(2 \times 20 \mathrm{~mL})$. The organic layer was dried over $\mathrm{Na}_{2} \mathrm{SO}_{4}$ and concentrated in vacuo. The residue was subjected to silica gel chromatography to give $\mathbf{4 a}$ as a yellow solid. Yield: $67 \%$. ${ }^{1} \mathrm{H}$ NMR $\left(\mathrm{CDCl}_{3}, 300 \mathrm{MHz}\right): \delta 3.96(\mathrm{~s}, 3 \mathrm{H}), 4.36(\mathrm{~d}$, $\mathrm{J}=5.4 \mathrm{~Hz}, 2 \mathrm{H}), 5.94(\mathrm{t}, \mathrm{J}=5.4 \mathrm{~Hz}, 1 \mathrm{H}), 7.27(\mathrm{~m}, 1 \mathrm{H}), 7.37(\mathrm{~m}, 1 \mathrm{H})$, $7.47(\mathrm{~m}, 1 \mathrm{H}), 7.73(\mathrm{~m}, 1 \mathrm{H}), 7.81(\mathrm{~m}, 1 \mathrm{H}), 8.22(\mathrm{~m}, 1 \mathrm{H}), 9.05(\mathrm{~m}, 1 \mathrm{H})$.

Ethyl 2-[(3-chlorophenylsulfonamido)methyl]thiazole-4carboxylate (4b)

The compound was prepared according to the procedure for $\mathbf{4 a}$ using ethyl 2-(aminomethyl)thiazole-4-carboxylate hydrobromide. Yield: 63\%. ${ }^{1} \mathrm{H} \mathrm{NMR}\left(\mathrm{CDCl}_{3}, 400 \mathrm{MHz}\right): \delta 1.37(\mathrm{t}, \mathrm{J}=6.8 \mathrm{~Hz}, 3 \mathrm{H})$, $4.36(\mathrm{q}, \mathrm{J}=6.8 \mathrm{~Hz}, 2 \mathrm{H}), 4.53(\mathrm{~d}, \mathrm{~J}=6.4 \mathrm{~Hz}, 2 \mathrm{H}), 5.79(\mathrm{t}, \mathrm{J}=6.4 \mathrm{~Hz}, 1 \mathrm{H})$, $7.42(\mathrm{~m}, 1 \mathrm{H}), 7.52(\mathrm{~m}, 1 \mathrm{H}), 7.73(\mathrm{~m}, 1 \mathrm{H}), 7.81(\mathrm{~m}, 1 \mathrm{H}), 8.09(\mathrm{~m}, 1 \mathrm{H})$.

\section{6-[(3-Chlorophenylsulfonamido)methyl]nicotinic acid (5a)}

Methyl 6-[(3-chlorophenylsulfonamido)methyl]nicotinate $(210 \mathrm{mg}$, $0.62 \mathrm{mmol})$ in $\mathrm{MeOH}$ was treated with $1 \mathrm{~mol} / \mathrm{L} \mathrm{KOH}(3 \mathrm{~mL})$ and stirred at $60^{\circ} \mathrm{C}$ for $4 \mathrm{~h}$. The $\mathrm{MeOH}$ was removed under reduced pressure. The residue was neutralized to $\mathrm{pH} 7$ with $1 \mathrm{~mol} / \mathrm{L} \mathrm{HCl}$ to give a white precipitate that was filtered to afford $5 \mathbf{a}$ as a white solid. Yield: 84\%. ${ }^{1} \mathrm{H}$ NMR (DMSO, $300 \mathrm{MHz}$ ): $\delta 4.20$ (s, 2H), 7.42 $(\mathrm{m}, 1 \mathrm{H}), 7.52(\mathrm{~m}, 1 \mathrm{H}), 7.62(\mathrm{~m}, 2 \mathrm{H}), 7.67(\mathrm{~m}, 1 \mathrm{H}), 8.13(\mathrm{~m}, 1 \mathrm{H}), 8.84$ $(\mathrm{m}, 1 \mathrm{H})$. 
2-[(3-Chlorophenylsulfonamido)methyl]thiazole-4-carboxylic acid (5b)

The compound was prepared according to the procedure for $5 \mathbf{a}$ using ethyl 2-[(3-chlorophenylsulfonamido)methyl]thiazole-4carboxylate. Yield: 81\%. ${ }^{1} \mathrm{H}$ NMR (DMSO, $300 \mathrm{MHz}$ ): $\delta 4.38$ (s, $2 \mathrm{H}), 7.58(\mathrm{~m}, 1 \mathrm{H}), 7.72(\mathrm{~m}, 3 \mathrm{H}), 8.35(\mathrm{~s}, 1 \mathrm{H})$.

\section{3-Chloro- $N$ - $\{[5-($ pyrrolidine-1-carbonyl)pyridin-2-yl]methyl $\}$} benzenesulfonamide (6a)

To a suspension of 6-[(3-chlorophenylsulfonamido)methyl]nicotinic acid (30 mg, $0.09 \mathrm{mmol})$ in $\mathrm{CH}_{2} \mathrm{Cl}_{2}(10 \mathrm{~mL})$ was added $\mathrm{HOBt}$ (14 mg, $0.1 \mathrm{mmol})$ and EDCI (31 mg, $0.16 \mathrm{mmol})$. After being stirred for $1 \mathrm{~h}$, pyrrolidine $(7.1 \mathrm{mg}, 0.1 \mathrm{mmol})$ was added and the resulting mixture was stirred for an additional $12 \mathrm{~h}$. The mixture was then washed with water $(3 \times 10 \mathrm{~mL})$. The organic layers were dried with $\mathrm{Na}_{2} \mathrm{SO}_{4}$ and concentrated in vacuo. The residue was subjected to silica gel chromatography to give 6a as a white solid. Yield: $70 \%$. ${ }^{1} \mathrm{H}$ NMR $\left(\mathrm{CDCl}_{3}, 300 \mathrm{MHz}\right): \delta 1.92(\mathrm{~m}, 4 \mathrm{H}), 3.39(\mathrm{t}$, $\mathrm{J}=6.3 \mathrm{~Hz}, 2 \mathrm{H}), 3.63(\mathrm{t}, \mathrm{J}=6.9 \mathrm{~Hz}, 2 \mathrm{H}), 4.32(\mathrm{~d}, \mathrm{~J}=5.4 \mathrm{~Hz}, 2 \mathrm{H}), 6.07$ $(\mathrm{t}, \mathrm{J}=5.4 \mathrm{~Hz}, 1 \mathrm{H}), 7.23(\mathrm{~m}, 1 \mathrm{H}), 7.38(\mathrm{~m}, 1 \mathrm{H}), 7.47(\mathrm{~m}, 1 \mathrm{H}), 7.74(\mathrm{~m}$, $1 \mathrm{H}), 7.76(\mathrm{~m}, 1 \mathrm{H}), 7.85(\mathrm{~m}, 1 \mathrm{H}), 8.61(\mathrm{~m}, 1 \mathrm{H})$. LR MS (EI) $\mathrm{m} / z 379$ $\left(\mathrm{M}^{+}\right), 315(100 \%)$; HR MS (EI) $m / z$ calc'd for $\mathrm{C}_{17} \mathrm{H}_{18} \mathrm{SClN}_{3} \mathrm{O}_{3}\left(\mathrm{M}^{+}\right)$ 379.0757, found 379.0741 .

\section{3-Chloro- $N$-\{[5-((2R,6S)-2,6-dimethylmorpholine-4-carbonyl)} pyridin-2-yl]methyl\}benzenesulfonamide (6b)

Using the procedure described earlier for $6 \mathbf{a}$ using $(2 R, 6 S)-2,6$ dimethylmorpholine, the title compound was obtained in $84 \%$ yield. ${ }^{1} \mathrm{H} \mathrm{NMR}\left(\mathrm{CDCl}_{3}, 300 \mathrm{MHz}\right): \delta 1.12(\mathrm{~m}, 3 \mathrm{H}), 1.24(\mathrm{~m}, 3 \mathrm{H})$, $2.56(\mathrm{~m}, 1 \mathrm{H}), 2.81(\mathrm{~m}, 1 \mathrm{H}), 3.38(\mathrm{~m}, 1 \mathrm{H}), 3.59(\mathrm{~m}, 2 \mathrm{H}), 4.33(\mathrm{~d}, \mathrm{~J}=5.7$ $\mathrm{Hz}, 2 \mathrm{H}), 4.53(\mathrm{~m}, 1 \mathrm{H}), 6.08(\mathrm{t}, \mathrm{J}=5.7 \mathrm{~Hz}, 1 \mathrm{H}), 7.27(\mathrm{~m}, 1 \mathrm{H}), 7.40(\mathrm{~m}$, $1 \mathrm{H}), 7.45(\mathrm{~m}, 1 \mathrm{H}), 7.69(\mathrm{~m}, 1 \mathrm{H}), 7.75(\mathrm{~m}, 1 \mathrm{H}), 7.86(\mathrm{~m}, 1 \mathrm{H}), 8.51(\mathrm{~m}$, 1H). LR MS (EI) m/z $423\left(\mathrm{M}^{+}\right), 359(100 \%)$; HR MS (EI) $m / z$ calc'd for $\mathrm{C}_{19} \mathrm{H}_{22} \mathrm{SClN}_{3} \mathrm{O}_{4}\left(\mathrm{M}^{+}\right)$423.1020, found 423.0922 .

\section{6-[(3-Chlorophenylsulfonamido)methyl]- $N, N$-diethylnicotinamide} (6c)

Using the procedure described earlier for $6 a$ using diethylamine, the title compound was obtained in $60 \%$ yield. ${ }^{1} \mathrm{H}$ NMR $\left(\mathrm{CDCl}_{3}\right.$, $400 \mathrm{MHz}): \delta 1.11(\mathrm{~m}, 3 \mathrm{H}), 1.21(\mathrm{~m}, 3 \mathrm{H}), 3.21(\mathrm{~m}, 2 \mathrm{H}), 3.52(\mathrm{~m}, 2 \mathrm{H})$, $4.31(\mathrm{~d}, \mathrm{~J}=5.6 \mathrm{~Hz}, 2 \mathrm{H}), 6.05(\mathrm{t}, \mathrm{J}=5.6 \mathrm{~Hz}, 1 \mathrm{H}), 7.23(\mathrm{~m}, 1 \mathrm{H}), 7.39(\mathrm{~m}$, $1 \mathrm{H}), 7.49(\mathrm{~m}, 1 \mathrm{H}), 7.64(\mathrm{~m}, 1 \mathrm{H}), 7.74(\mathrm{~m}, 1 \mathrm{H}), 7.87(\mathrm{~m}, 1 \mathrm{H}), 8.48(\mathrm{~m}$, $1 \mathrm{H})$. LR MS (EI) $m / z 381\left(\mathrm{M}^{+}\right), 317(100 \%) ; \mathrm{HR}$ MS (EI) $m / z$ calc'd for $\mathrm{C}_{17} \mathrm{H}_{20} \mathrm{SClN}_{3} \mathrm{O}_{3}\left(\mathrm{M}^{+}\right)$381.0914, found 381.0880.

\section{3-Chloro- $N$-\{[5-(piperidine-1-carbonyl)pyridin-2-yl]methyl\}} benzenesulfonamide $(6 \mathrm{~d})$

Using the procedure described earlier for 6 a using piperidine, the title compound was obtained in $70 \%$ yield. ${ }^{1} \mathrm{H}$ NMR $\left(\mathrm{CDCl}_{3}, 300\right.$ $\mathrm{MHz})$ : $\delta 1.55-1.82(\mathrm{~m}, 6 \mathrm{H}), 3.30(\mathrm{~m}, 2 \mathrm{H}), 3.71(\mathrm{~m}, 2 \mathrm{H}), 4.31(\mathrm{~d}, \mathrm{~J}=5.4$ $\mathrm{Hz}, 2 \mathrm{H}), 6.10(\mathrm{t}, \mathrm{J}=5.4 \mathrm{~Hz}, 1 \mathrm{H}), 7.23(\mathrm{~m}, 1 \mathrm{H}), 7.37(\mathrm{~m}, 1 \mathrm{H}), 7.43(\mathrm{~m}$, $1 \mathrm{H}), 7.65(\mathrm{~m}, 1 \mathrm{H}), 7.73(\mathrm{~m}, 1 \mathrm{H}), 7.85(\mathrm{~m}, 1 \mathrm{H}), 8.47(\mathrm{~m}, 1 \mathrm{H})$. LR MS (EI) $m / z 393\left(\mathrm{M}^{+}\right), 329(100 \%)$; HR MS (EI) $m / z$ calc'd for $\mathrm{C}_{18} \mathrm{H}_{20} \mathrm{~S}-$ $\mathrm{ClN}_{3} \mathrm{O}_{3}\left(\mathrm{M}^{+}\right)$393.0914, found 393.0895.

\section{6-[(3-Chlorophenylsulfonamido)methyl]- $N$-cycloheptylnicotina-} mide (6e)

Using the procedure described earlier for 6 a using cycloheptanamine, the title compound was obtained in $82 \%$ yield. ${ }^{1} \mathrm{H}$ NMR $\left(\mathrm{CDCl}_{3}, 300 \mathrm{MHz}\right)$ : $\delta 1.53-1.67(\mathrm{~m}, 10 \mathrm{H}), 1.99(\mathrm{~m}, 2 \mathrm{H}), 4.14(\mathrm{~m}, 1 \mathrm{H})$, $4.38(\mathrm{~m}, 2 \mathrm{H}), 6.42(\mathrm{~m}, 1 \mathrm{H}), 6.56(\mathrm{~m}, 1 \mathrm{H}), 7.35(\mathrm{~m}, 2 \mathrm{H}), 7.47(\mathrm{~m}, 1 \mathrm{H})$, $7.73(\mathrm{~m}, 1 \mathrm{H}), 7.79(\mathrm{~m}, 1 \mathrm{H}), 8.12(\mathrm{~m}, 1 \mathrm{H}), 8.89(\mathrm{~m}, 1 \mathrm{H})$. LR MS (EI) $m / z 421\left(\mathrm{M}^{+}\right), 357(100 \%)$; HR MS (EI) $m / z$ calc'd for $\mathrm{C}_{20} \mathrm{H}_{24} \mathrm{SClN}_{3} \mathrm{O}_{3}$ $\left(\mathrm{M}^{+}\right)$421.1224, found 421.1209.

6-[(3-Chlorophenylsulfonamido)methyl]-N-cycloheptyl-Nmethylnicotinamide (6f)

Using the procedure described earlier for 6a using $N$-methylcycloheptanamine, the title compound was obtained in $32 \%$ yield. ${ }^{1} \mathrm{H}$ NMR $\left(\mathrm{CDCl}_{3}, 300 \mathrm{MHz}\right): \delta$ 1.24-1.88 (m, 12H), 2.80/2.97 (2×s, $3 \mathrm{H}), 3.51 / 4.52(2 \times \mathrm{m}, 1 \mathrm{H}), 4.35(\mathrm{~m}, 2 \mathrm{H}), 6.35 / 6.47(2 \times \mathrm{m}, 1 \mathrm{H}), 7.34$ (m, 1H), 7.39 (m, 1H), $7.49(\mathrm{~m}, 1 \mathrm{H}), 7.69(\mathrm{~m}, 2 \mathrm{H}), 7.85(\mathrm{~m}, 1 \mathrm{H}), 8.48$ (m, 1H). LR MS (EI) m/z $435\left(\mathrm{M}^{+}\right), 340(100 \%)$; HR MS (EI) $m / z$ calc'd for $\mathrm{C}_{21} \mathrm{H}_{26} \mathrm{SClN}_{3} \mathrm{O}_{3}\left(\mathrm{M}^{+}\right)$435.1383, found 435.1391.

6-[(3-Chlorophenylsulfonamido)methyl]-N-cycloheptyl-Npropylnicotinamide $(6 \mathrm{~g})$

Using the procedure described earlier for 6a using $N$-propylcycloheptanamine, the title compound was obtained in $30 \%$ yield. ${ }^{1} \mathrm{H}$ NMR $\left(\mathrm{CDCl}_{3}, 300 \mathrm{MHz}\right)$ : $\delta$ 0.69-1.94 (m, 17H), 3.05/3.25/3.45 $(3 \times \mathrm{m}, 3 \mathrm{H}), 4.36(\mathrm{~m}, 2 \mathrm{H}), 6.38(\mathrm{~m}, 1 \mathrm{H}), 7.36(\mathrm{~m}, 1 \mathrm{H}), 7.43(\mathrm{~m}, 1 \mathrm{H})$, $7.51(\mathrm{~m}, 1 \mathrm{H}), 7.72(\mathrm{~m}, 2 \mathrm{H}), 7.88(\mathrm{~m}, 1 \mathrm{H}), 8.45$ (m, 1H). LR MS (EI) $m / z 463\left(\mathrm{M}^{+}\right), 368(100 \%)$; HR MS (EI) $m / z$ calc ${ }^{\prime} \mathrm{d}$ for $\mathrm{C}_{23} \mathrm{H}_{30} \mathrm{SClN}_{3} \mathrm{O}_{3}$ $\left(\mathrm{M}^{+}\right)$463.1696, found 463.1694.

\section{$N$-butyl-6-[(3-chlorophenylsulfonamido)methyl]-N-cycloheptyl-} nicotinamide $(6 \mathrm{~h})$

Using the procedure described earlier for 6a using $N$-butylcycloheptanamine, the title compound was obtained in 33\% yield. ${ }^{1} \mathrm{H}$ NMR $\left(\mathrm{CDCl}_{3}, 300 \mathrm{MHz}\right)$ : $\delta$ 0.74-2.05 (m, 19H), 3.07/3.32/3.45 $(3 \times \mathrm{m}, 3 \mathrm{H}), 4.39(\mathrm{~m}, 2 \mathrm{H}), 6.40(\mathrm{~m}, 1 \mathrm{H}), 7.40(\mathrm{~m}, 2 \mathrm{H}), 7.51(\mathrm{~m}, 1 \mathrm{H})$, $7.75(\mathrm{~m}, 2 \mathrm{H}), 7.88(\mathrm{~m}, 1 \mathrm{H}), 8.47(\mathrm{~m}, 1 \mathrm{H})$. LR MS (EI) $\mathrm{m} / z 477$ $\left(\mathrm{M}^{+}\right), 134(100 \%)$; HR MS (EI) $m / z$ calc'd for $\mathrm{C}_{24} \mathrm{H}_{32} \mathrm{SClN}_{3} \mathrm{O}_{3}\left(\mathrm{M}^{+}\right)$ 477.1853 , found 477.1840 .

\section{3-Chloro-N-\{[4-(pyrrolidine-1-carbonyl)thiazol-2-yl]methyl} benzenesulfonamide (7a)

Using the procedure described earlier for $\mathbf{6} \mathbf{a}$ using $\mathbf{5 b}$ and pyrrolidine, the title compound was obtained in $60 \%$ yield. ${ }^{1} \mathrm{H}$ NMR $\left(\mathrm{CDCl}_{3}, 300 \mathrm{MHz}\right): \delta 1.87(\mathrm{~m}, 4 \mathrm{H}), 3.58(\mathrm{t}, \mathrm{J}=6.3 \mathrm{~Hz}, 2 \mathrm{H}), 3.72(\mathrm{t}$, $\mathrm{J}=6.3 \mathrm{~Hz}, 2 \mathrm{H}), 4.48(\mathrm{~m}, 2 \mathrm{H}), 6.34(\mathrm{~m}, 1 \mathrm{H}), 7.40(\mathrm{~m}, 1 \mathrm{H}), 7.52(\mathrm{~m}$, $1 \mathrm{H}), 7.74(\mathrm{~m}, 1 \mathrm{H}), 7.88(\mathrm{~m}, 1 \mathrm{H}), 7.89(\mathrm{~m}, 1 \mathrm{H})$. LR MS (EI) $m / z 385$ $\left(\mathrm{M}^{+}\right), 70(100 \%)$; HR MS (EI) $m / z$ calc'd for $\mathrm{C}_{15} \mathrm{H}_{16} \mathrm{~S}_{2} \mathrm{ClN}_{3} \mathrm{O}_{3}\left(\mathrm{M}^{+}\right)$ 385.0322 , found 385.0326 .

\section{3-Chloro- $N$ - $\{[$ 4-((2R,6S)-2,6-dimethylmorpholine-4-carbonyl)} thiazol-2-yl]methyl\}benzenesulfonamide (7b)

Using the procedure described earlier for $\mathbf{6} \mathbf{a}$ using $5 \mathbf{b}$ and $(2 R, 6 S)$ 2,6-dimethylmorpholine, the title compound was obtained in $70 \%$ yield. ${ }^{1} \mathrm{H}$ NMR $\left(\mathrm{CDCl}_{3}, 300 \mathrm{MHz}\right): \delta 1.15-1.31(\mathrm{~m}, 8 \mathrm{H}), 2.49(\mathrm{~m}$, $1 \mathrm{H}), 2.79(\mathrm{~m}, 1 \mathrm{H}), 3.59(\mathrm{~m}, 2 \mathrm{H}), 4.46(\mathrm{~d}, \mathrm{~J}=6.3 \mathrm{~Hz}, 2 \mathrm{H}), 6.29(\mathrm{t}, \mathrm{J}=6.3$ $\mathrm{Hz}, 1 \mathrm{H}), 7.43(\mathrm{t}, \mathrm{J}=8.1 \mathrm{~Hz}, 1 \mathrm{H}), 7.55(\mathrm{~m}, 1 \mathrm{H}), 7.76(\mathrm{~m}, 2 \mathrm{H}), 7.90(\mathrm{~m}$, 1H). LR MS (EI) $m / z 429\left(\mathrm{M}^{+}\right), 114(100 \%) ;$ HR MS (EI) $m / z$ calc'd for $\mathrm{C}_{17} \mathrm{H}_{20} \mathrm{~S}_{2} \mathrm{ClN}_{3} \mathrm{O}_{4}\left(\mathrm{M}^{+}\right)$429.0584, found 429.0583 .

\section{2-[(3-Chlorophenylsulfonamido)methyl]- $N, N$-diethylthiazole-4-} carboxamide (7c)

Using the procedure described earlier for $\mathbf{6 a}$ using $\mathbf{5 b}$ and diethylamine, the title compound was obtained in $69 \%$ yield. ${ }^{1} \mathrm{H}$ NMR $\left(\mathrm{CDCl}_{3}, 300 \mathrm{MHz}\right)$ : $\delta 1.11(\mathrm{~m}, 6 \mathrm{H}), 3.46(\mathrm{~m}, 4 \mathrm{H}), 4.43(\mathrm{~m}, 2 \mathrm{H})$, 
$6.51(\mathrm{~m}, 1 \mathrm{H}), 7.42(\mathrm{t}, \mathrm{J}=7.8 \mathrm{~Hz}, 1 \mathrm{H}), 7.53(\mathrm{~m}, 1 \mathrm{H}), 7.68(\mathrm{~s}, 1 \mathrm{H}), 7.76$ (m, 1H), 7.90 (m, 1H). LR MS (EI) m/z $387\left(\mathrm{M}^{+}\right), 72$ (100\%); HR MS (EI) $\mathrm{m} / z$ calc'd for $\mathrm{C}_{15} \mathrm{H}_{18} \mathrm{~S}_{2} \mathrm{ClN}_{3} \mathrm{O}_{3}\left(\mathrm{M}^{+}\right)$387.0478, found 387.0486.

\section{3-Chloro-N-\{[4-(piperidine-1-carbonyl)thiazol-2-yl]methyl\} benzenesulfonamide $(7 \mathrm{~d})$}

Using the procedure described earlier for $\mathbf{6 a}$ using $\mathbf{5 b}$ and piperidine, the title compound was obtained in $58 \%$ yield. ${ }^{1} \mathrm{H}$ NMR $\left(\mathrm{CDCl}_{3}, 300 \mathrm{MHz}\right): \delta 1.53-1.72(\mathrm{~m}, 6 \mathrm{H}), 3.55(\mathrm{~m}, 2 \mathrm{H}), 3.66(\mathrm{~m}, 2 \mathrm{H})$, $4.45(\mathrm{~d}, \mathrm{~J}=6.3 \mathrm{~Hz}, 2 \mathrm{H}), 6.09(\mathrm{t}, \mathrm{J}=6.3 \mathrm{~Hz}, 1 \mathrm{H}), 7.42(\mathrm{t}, \mathrm{J}=8.1 \mathrm{~Hz}, 1 \mathrm{H})$, $7.53(\mathrm{~m}, 1 \mathrm{H}), 7.65(\mathrm{~s}, 1 \mathrm{H}), 7.75(\mathrm{~m}, 1 \mathrm{H}), 7.89(\mathrm{~m}, 1 \mathrm{H})$. LR MS (EI) $m / z 399\left(\mathrm{M}^{+}\right), 84(100 \%)$; HR MS (EI) $m / z$ calc'd for $\mathrm{C}_{16} \mathrm{H}_{18} \mathrm{~S}_{2} \mathrm{ClN}_{3} \mathrm{O}_{3}$ $\left(\mathrm{M}^{+}\right)$399.0478, found 399.0472.

\section{2-[(3-chlorophenylsulfonamido)methyl]-N-cycloheptylthiazole-4- carboxamide $(7 \mathrm{e})$}

Using the procedure described earlier for $\mathbf{6 a}$ using $5 \mathbf{b}$ and cycloheptanamine, the title compound was obtained in $62 \%$ yield. ${ }^{1} \mathrm{H}$ NMR $\left(\mathrm{CDCl}_{3}, 300 \mathrm{MHz}\right)$ : $\delta$ 1.53-1.70 (m, 10H), $1.97(\mathrm{~m}, 2 \mathrm{H}), 4.08$ $(\mathrm{m}, 1 \mathrm{H}), 4.51(\mathrm{~m}, 2 \mathrm{H}), 5.58(\mathrm{~m}, 1 \mathrm{H}), 7.08(\mathrm{~m}, 1 \mathrm{H}), 7.41(\mathrm{t}, \mathrm{J}=7.8$ $\mathrm{Hz}, 1 \mathrm{H}), 7.53(\mathrm{~m}, 1 \mathrm{H}), 7.73(\mathrm{~m}, 1 \mathrm{H}), 7.84(\mathrm{~s}, 1 \mathrm{H}), 7.98(\mathrm{~m}, 1 \mathrm{H})$. LR MS (EI) $m / z 427\left(\mathrm{M}^{+}\right), 112(100 \%)$; HR MS (EI) $m / z$ calc'd for $\mathrm{C}_{18} \mathrm{H}_{22} \mathrm{~S}_{2} \mathrm{ClN}_{3} \mathrm{O}_{3}\left(\mathrm{M}^{+}\right)$427.0791, found 427.0792.

\section{2-[(3-chlorophenylsulfonamido)methyl]-N-cycloheptyl- $\mathrm{N}$-methyl- thiazole-4-carboxamide (7f)}

Using the procedure described earlier for $\mathbf{6 a}$ using $\mathbf{5 b}$ and $\mathrm{N}$-methylcycloheptanamine, the title compound was obtained in $26 \%$ yield. ${ }^{1} \mathrm{H}$ NMR $\left(\mathrm{CDCl}_{3}, 300 \mathrm{MHz}\right): \delta$ 1.46-1.97 (m, 12H), 2.96 $(\mathrm{s}, 3 \mathrm{H}), 4.03(\mathrm{~m}, 1 \mathrm{H}), 4.48(\mathrm{~m}, 2 \mathrm{H}), 6.10(\mathrm{~m}, 1 \mathrm{H}), 7.43(\mathrm{~m}, 1 \mathrm{H}), 7.54$ $(\mathrm{m}, 1 \mathrm{H}), 7.68(\mathrm{~m}, 1 \mathrm{H}), 7.75(\mathrm{~m}, 1 \mathrm{H}), 7.89(\mathrm{~m}, 1 \mathrm{H})$. LR MS (EI) $\mathrm{m} / \mathrm{z}$ $441\left(\mathrm{M}^{+}\right), 126(100 \%)$; HR MS (EI) $\mathrm{m} / z$ calc'd for $\mathrm{C}_{19} \mathrm{H}_{24} \mathrm{~S}_{2} \mathrm{ClN}_{3} \mathrm{O}_{3}$ $\left(\mathrm{M}^{+}\right)$441.0948, found 441.0961 .

\section{2-[(3-chlorophenylsulfonamido)methyl]-N-cycloheptyl-N-} propylthiazole-4-carboxamide (7g)

Using the procedure described earlier for $\mathbf{6 a}$ using $\mathbf{5 b}$ and $N$-propylcycloheptanamine, the title compound was obtained in 33\% yield. ${ }^{1} \mathrm{H}$ NMR $\left(\mathrm{CDCl}_{3}, 300 \mathrm{MHz}\right): \delta$ 0.76-1.86 (m, 17H), $3.22(\mathrm{~m}$, $2 \mathrm{H}), 3.94-4.14(\mathrm{~m}, 1 \mathrm{H}), 4.44(\mathrm{~m}, 2 \mathrm{H}), 6.21(\mathrm{~m}, 1 \mathrm{H}), 7.42(\mathrm{~m}, 1 \mathrm{H})$, $7.54(\mathrm{~m}, 1 \mathrm{H}), 7.67(\mathrm{~m}, 1 \mathrm{H}), 7.76(\mathrm{~m}, 1 \mathrm{H}), 7.90(\mathrm{~m}, 1 \mathrm{H})$. LR MS (EI) $m / z 469\left(\mathrm{M}^{+}\right), 154(100 \%)$; HR MS (EI) $m / z$ calc'd for $\mathrm{C}_{21} \mathrm{H}_{28} \mathrm{~S}_{2} \mathrm{ClN}_{3} \mathrm{O}_{3}$ $\left(\mathrm{M}^{+}\right)$469.1261, found 469.1244.

\section{$N$-butyl-2-[(3-chlorophenylsulfonamido)methyl]-N-cycloheptyl- thiazole-4-carboxamide (7h) \\ Using the procedure described earlier for $\mathbf{6 a}$ using $5 \mathbf{b}$ and $N$-bu- tylcycloheptanamine, the title compound was obtained in $27 \%$ yield. ${ }^{1} \mathrm{H} \mathrm{NMR}\left(\mathrm{CDCl}_{3}, 300 \mathrm{MHz}\right): \delta 0.82-1.90(\mathrm{~m}, 19 \mathrm{H}), 3.32(\mathrm{~m}$, 2H), $4.01(\mathrm{~m}, 1 \mathrm{H}), 4.43(\mathrm{~m}, 2 \mathrm{H}), 6.09(\mathrm{~m}, 1 \mathrm{H}), 7.45(\mathrm{~m}, 1 \mathrm{H}), 7.54(\mathrm{~m}$, $1 \mathrm{H}), 7.67(\mathrm{~m}, 1 \mathrm{H}), 7.76(\mathrm{~m}, 1 \mathrm{H}), 7.88(\mathrm{~m}, 1 \mathrm{H})$. LR MS (EI) $\mathrm{m} / z 483$ $\left(\mathrm{M}^{+}\right), 168(100 \%)$; HR MS (EI) $m / z$ calc'd for $\mathrm{C}_{21} \mathrm{H}_{28} \mathrm{~S}_{2} \mathrm{ClN}_{3} \mathrm{O}_{3}\left(\mathrm{M}^{+}\right)$ 483.1417, found 483.1413 .}

\section{Acknowledgments}

We gratefully acknowledge financial support from the National Basic Research Program of China (973 Program, 2009CB522300) and the National Natural Science Foundation of China (Grant 90813029). The project was also supported by the Science and Technology Commission of Shanghai Municipality (Grants 08QH14028 and 08ZR1422600).

\section{Author contribution}

Jian-hua SHEN and Ying LENG designed the research; $\mathrm{Xu}$ ZHANG, Yang ZHOU, Yu SHEN, and Li-li DU performed the experiments; Xu ZHANG and Jun-hua CHEN analyzed data; $\mathrm{Xu}$ ZHANG and Yang ZHOU wrote the manuscript.

\section{References}

1 Skyler JS. Diabetes mellitus: pathogenesis and treatment strategies. J Med Chem 2004; 47: 4113-7.

2 Hanson RW, Reshef L. Regulation of phosphoenolpyruvate carboxykinase (GTP) gene. Annu Rev Biochem 1997; 66: 581-611.

3 Bujalska IJ, Kumar S, Hewison M, Stewart PM. Differentiation of adipose stromal cells: the roles of glucocorticoids and 11 betahydroxysteroid dehydrogenase. Endocrinology 1999; 140: 3188-96.

4 Tomlinson JW, Walker EA, Bujalska IJ, Draper N, Lavery GG, Cooper $\mathrm{MS}$, et al. 11 Beta-hydroxysteroid dehydrogenase type 1: a tissuespecific regulator of glucocorticoid response. Endocr Rev 2004; 25: 831-66.

5 Stulnig TM, WaldhausI W. 11 Beta-hydroxysteroid dehydrogenase type 1 in obesity and type 2 diabetes. Diabetologia 2004; 47: 1-11.

6 Masuzaki H, Paterson J, Shinyama H, Morton NM, Mullins JJ, Seckl $\mathrm{JR}$, et al. A transgenic model of visceral obesity and the metabolic syndrome. Science 2001; 294: 2166-70.

7 Paterson JM, Morton NM, Fievet C, Kenyon CJ, Holmes MC, Staels B, et al. Metabolic syndrome without obesity: hepatic overexpression of 11 beta-hydroxysteroid dehydrogenase type 1 in transgenic mice. Proc Natl Acad Sci USA 2004; 101: 7088-93.

8 Morton NM, Paterson JM, Masuzaki H, Holmes MC, Staels B, Fievet $C$, et al. Novel adipose tissue-mediated resistance to diet-induced visceral obesity in 11 beta-hydroxysteroid dehydrogenase type 1-deficient mice. Diabetes 2004; 53: 931-8.

9 Kotelevtsev Y, Holmes MC, Burchell A, Houston PM, Schmoll D, Jamieson $\mathrm{P}$, et al. 11beta-Hydroxysteroid dehydrogenase type 1 knockout mice show attenuated glucocorticoid-inducible responses and resist hyperglycemia on obesity or stress. Proc Natl Acad Sci USA 1997; 94: 14924-9.

10 Fotsch C, Wang M. Blockade of glucocorticoid excess at the tissue level: inhibitors of 11beta-hydroxysteroid dehydrogenase type 1 as a therapy for type 2 diabetes. J Med Chem 2008; 51: 4851-7.

11 Koerberple K, Massiot G. Total synthesis of nosiheptide - synthesis of thiazole fragments. J Heterocycl Chem 1995; 32: 1309-15.

12 Mattson RJ, Pham KM, Leuck DJ, Cowen KA. An improved method for reductive alkylation of amines using titanium(iv) isopropoxide and sodium cyanoborohydride. J Org Chem 1990; 55: 2552-4.

13 Mundt S, Solly K, Thieringer R, Hermanowski-Vosatka A. Development and application of a scintillation proximity assay (SPA) for identification of selective inhibitors of 11 beta-hydroxysteroid dehydrogenase type 1. Assay Drug Dev Technol 2005; 3: 367-75.

14 Yang HY, Shen Y, Chen JH, Jiang QF, Leng Y, Shen JH. Structure-based virtual screening for identification of novel 11[beta]-HSD1 inhibitors. Eur J Med Chem 2009; 44: 1167-71.

15 Discovery Studio 2.1. San Diego (California, USA): Accelrys Software Inc; 2008.

16 Glide and Maestro. New York (NY): Schrödinger, LLC; 2005.

17 PyMOL Molecular Graphics System. v0.99. Palo Alto (CA, USA): DeLano Scientific; 2006. 